E Q U I L I B R I U M

2 ( 5 ) 2010

ISSN 1689-765X

Agata Osińska, Grzegorz Tchorek

\title{
Financial Crisis and Changes in the International Monetary System. Implications for Euro
}

Key words: international currency, the euro, the crisis, monetary regime, monetary integration

\begin{abstract}
Having an international currency brings some benefits but also important obstacles. Undoubtedly, it is positive to have international money but the process of achieving the status of global money may lead to some costs connected with the appreciation of the euro. The main goal of this article is to show that one of the probable scenarios of the post-crisis adjustment in the international monetary system is the risk of the euro overvaluation. It can be a result of the diminishing role of the U.S. economy and the growing role of the euro as an international currency. Paradoxically, thanks to its success, the euro can be exposed to the overvaluation with important implication for the euro area countries as well as candidate countries.
\end{abstract}

\section{INTRODUCTION}

Global imbalances, which mainly occurred between the U.S. and exporting countries, had a significant influence on the occurrence and course of the current financial and economic crisis (2007-2009). With high probability correcting the imbalance in the global economic system will contribute to significant changes in the international monetary system. They are potentially related to the following factors.

Firstly, they are associated with a fall in the dollar exchange rate as a consequence of restoring of the U.S. external balance. They are also related to the further gradual diminishing of the U.S. role in the international economic system.

Secondly, they are connected with the growing importance of the SDR as an international currency, as a consequence of the evolution of the international economic, financial and monetary system architecture. This process is likely 
to be accompanied by a consolidation around regional currency (yuan, ruble, the currency of the Arab countries).

The third factor is the appreciation of the euro, as a young currency, based on the economies of the largest member countries, the credibility of the ECB and the European institutions.

It is difficult to assess accurately the intensity and the time in which the processes will overlap, hence they must be taken as a research hypothesis. However, in the present circumstances they are justified economically. Moreover, these processes will probably coexist and intensity of one of them may be dependent on the intensity of the others.

\section{THE COURSE OF THE CRISIS AND THE BEHAVIOUR OF USD}

According to Fratzscher (2009), the widespread expectation before the crisis showed the need for the depreciation of the U.S. dollar as one of the factors that would restore balance in the international economic system (Fratzscher, M., 2009). Paradoxically, entry into the most severe phase of the financial turmoil (mid 2008) contributed to the appreciation of the dollar against the currencies of almost all the international financial system. This should be associated with a sharp increase in risk aversion and flight to assets with high credibility and liquidity (flight to quality, flight to liquidity). The freezing of the global interbank market, as a result of bankruptcies of the financial institutions and the rapid loss of mutual confidence of market participants, increased the pressure on liquidity (cash). On the other hand, it led to the search for assets with traditionally high reliability. U.S. dollar, which allowed access to the U.S. treasury securities, commodity markets, and many other currencies took the safe haven function (Elsake 2009). Another factor that stimulated the appreciation of the dollar were the prospects for the interest rate cuts by major central banks. In the second half of 2008 in the countries with low interest rates (the U.S. and Japan), the space for their further reduction was rather limited, which positively influenced the perceptions of these currencies (NBP, Report, 2009).

Investors' expectations suggest that one of the signs showing that the crisis can be overcome may be a depreciation of the dollar. Then, as a result of the global economy returning onto a growth path, aversion to risk decreases. At the same time there may occur the monetization of U.S. debt in the form of higher inflation. With the huge debt and the exorbitant privilege of having an international currency, Americans may try to repay their debt with poorer quality dollar (subject to inflation). This would mean shifting the cost of debt to creditors who have received weaker purchasing power dollars. In addition, a relatively much milder course of the crisis in some developing countries than in developed ones may lead to the influx of capital to these countries. If the U.S. had more serious 
problems with the restructuring of public finance than other countries in the future, there would be a risk of investors preferring treasury securities of emerging market countries.

\section{Public finance}

Sources of increased uncertainty about the condition of the U.S. economy and its future stem from the scale of fiscal and monetary intervention. Due to the need for significant action to rescue the bankruptcy-threatened financial institutions and the spread of the crisis, extraordinary measures were taken which contributed to the rapid growth of public debt and increasing the monetary base.

The depreciation of the dollar as the main currency of the world is explained on the basis of economic and financial issues. This is due to the huge U.S. debt that has been accumulated for many years in the private sector as a result of the low savings rates of the U.S. households and is expressed in a high current account deficits and net investment position ${ }^{1}$. In the year 2009, the budget deficit in the United States for the first time in history was more than 1 trillion U.S. dollars and according to extremely pessimistic forecasts it will reach 2 trillion U.S. dollars. It is estimated that in 2009 budget deficit was around 11-13\% of GDP and in 2010 it will be around $9.7 \%$ of GDP. As a result, in 2010 public debt could rise to just over $90 \%$ of GDP and in 2011 it can reach close almost $100 \%$ - see Figure 1.

Figure 1. Public debt as \% of GDP in selected OECD countries

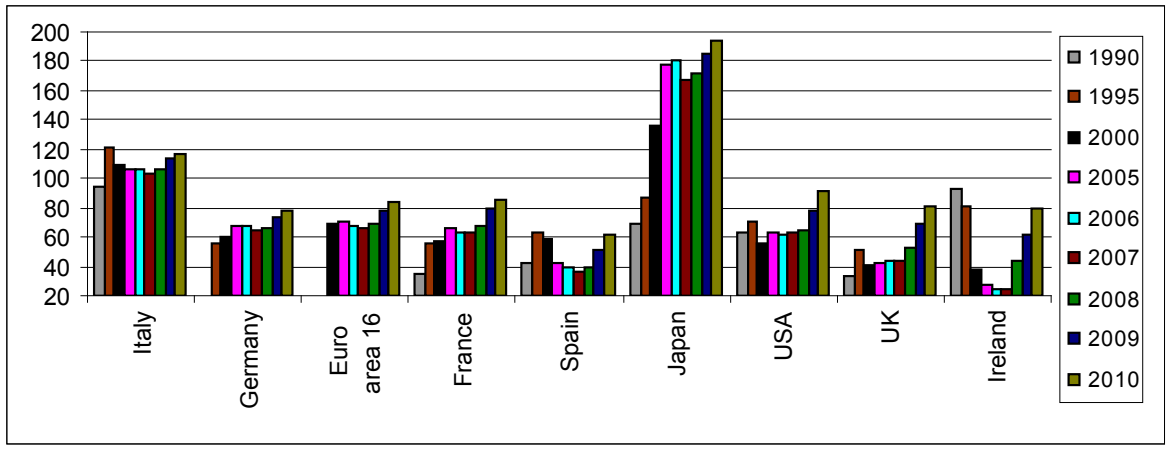

Source: Base of AMECO.

${ }^{1}$ Between 2000-2008 the U.S. negative trade balance increased gradually from less than USD 400 billion to more than 700 billion. It was on average 1.5-2.5 times larger than the trade deficit of all OECD countries. 


\section{Monetary POLicy}

The second source of concern about the condition of the U.S. dollar were the extraordinary actions which were taken by the Fed in reducing the price of money, injection of liquidity in the financial system and the emergency measures in the form of quantitative loosening of monetary policy (quantitative easing). Basic Fed interest rates were cut from just over 5\% in the second half of 2007 to $2 \%$ in the middle of 2008. As a result of escalating financial turmoil and the collapse of credit, trade and investment, interest rates were reduced to $0.25 \%$ in mid 2009 .

At the same time the Fed said that the traditional interest rate mechanism was insufficient to restore liquidity in the financial system, so it used a new channel through the intervention by redemption of bank assets. These actions led to the increase in the Fed balance amount by $100 \%$ over two months at the end of 2008. At the beginning of 2009, total assets increased 2.5 times. Operations included broadening the pool of assets that are accepted as a collateral in transactions with the central bank, buying market instruments and an unlimited supply of dollar liquidity - see Figure 2.

Figure 2. Changes in the Fed's balance

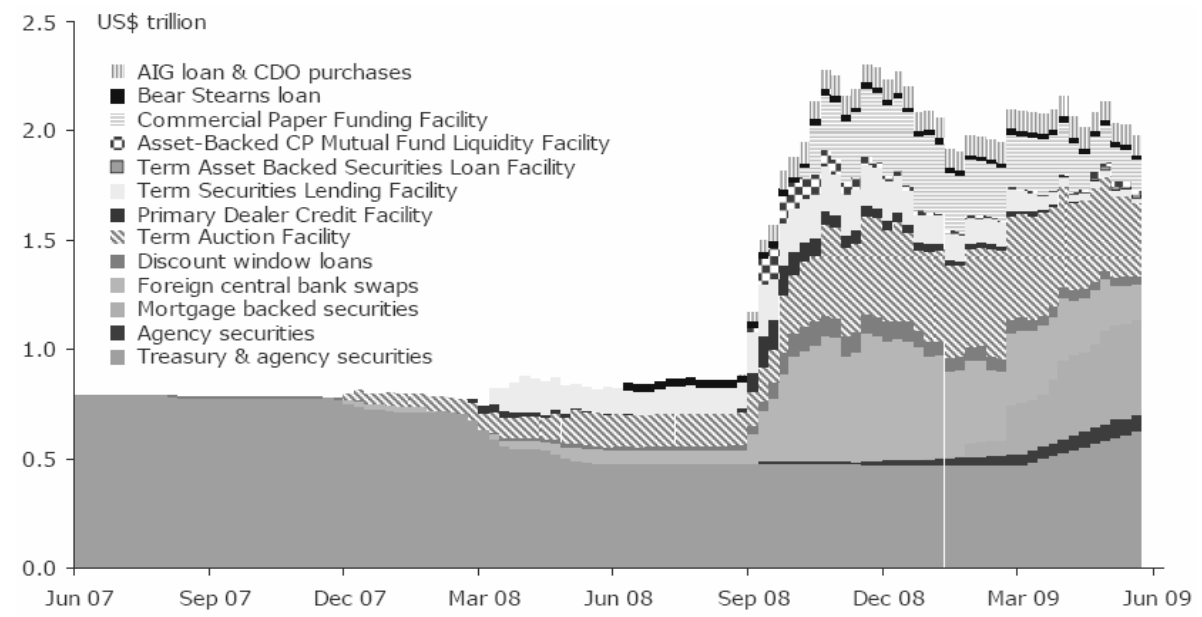

Source: FED: Elsake S. Is the US Dollar in Danger of Losing its Reserve Currency Status?, Australia and New Zeland Banking Group Ltd., July 2009.

The extraordinary scale and scope of operation to reduce the price of money provide liquidity and take pro-demand action in fiscal policy raise concern about the outbreak of inflation and the erosion of the dollar. On the one hand, the risk of inflation results from expansionary monetary and fiscal policies. On the other hand, the U.S. deliberately wants to use inflation for the reduction of the real value of debt accumulated in the private and public sectors. 


\section{Credit rating}

After the government sector took over a large part of the debts and problems accumulated in the financial system, increased government debt led to a reduction of credit ratings of countries such as Greece, Spain and Ireland (twice the reduction since the beginning of 2009). In the third decade of May 2009 the rating agency S \& P downgraded the rating outlook for the UK. The bad condition of the British economy and the soaring debt (30 p.p. of GDP over the years 2008-2010) raised a similar concern to that expressed also by Moodys Investors Services. The importance of the U.S. financial sector and the problems it caused gave rise to a wave of financial market speculation that the United States could also lose the highest credit scores. Although the reduction in the risk assessment of the credibility of the largest countries rated AAA is not materialized at the end of September 2009, Fitch Ratings agency reiterated its concerns about the prospects for the rating of these countries due to increasing vulnerability of public finances.

Despite the enormous economic and financial problems, the risk of downgrading rating for the United States is lower than in other countries. Because the dollar is a reserve currency, the United States is in a better position than other indebted countries. Given the economic, political and military potential of the U.S., investors are willing to accept a large deficit provided that credible economic recovery program is implemented. This is due to inertial confidence in the highly innovative U.S. economy, with a flexible labour market, well-established co-operation between $\mathrm{R}+\mathrm{D}$ and production sectors. The U.S. economy is still highly competitive, which is confirmed by the relatively high positions in rankings of competitiveness, e.g. Doing Business ( ${ }^{\text {th }}$ place), Word Economic Forum ( $2^{\text {nd }}$ place).

Certainly, the economic policy of the United States after 2001 gives arguments in favour of reducing the role of the dollar in the international financial system. However, the scale of the use of the dollar in international business transactions and the network effects mean that the dollar can enjoy the status of a global currency much longer. This may mean that in the scenario of reducing the role of the U.S. economy in the world economic system, the dollar will be subject to rather gradual depreciation. USD stability may be the result of its significant dominance in foreign exchange reserves, stock prices of raw materials and currency changeover. 


\section{Changing Role of the IMF}

\section{AND THE GROWING IMPORTANCE OF SDR}

Financial turmoil and an extraordinary action taken in respect of fiscal and monetary policies in response to the crisis in the U.S. worried market participants because of the risk of a sharp weakening of the dollar and the loss of the leading currency in the international monetary system. Specific objections were expressed by the countries that are major creditors of the United States: China and Russia. Including India and Brazil, these countries form the BRIC group, holding the world's largest foreign exchange reserves.

China's proposal calling for a reform of the international monetary system, expressed by the Governor of the People's Bank of China in March 2009, boils down to enhancing the role of the SDR as an international currency. Instead of mainly U.S. dollars, central banks, would keep SDR, whose value corresponds to the basket of currencies (44\% of USD, $34 \%$ of EUR, $11 \%$ of $£, 11 \%$ of JPY). International money under this proposal should be linked with a stable benchmark, according to commonly accepted rules, and should not reflect the economic condition of a single country.

This proposal includes demands for increasing the role and the importance of developing countries in the world economic system and increasing their role in the IMF. Without a doubt, the IMF has played an important role in mitigating the effects of the crisis. A significant change is visible in the philosophy of the IMF's stabilizing role, which is evolving from ex post actions towards ex ante intervention (more flexible conditions than in the past). The first-ever issuance of bonds suggests that the IMF may be becoming the central bank of the world. Therefore, a future role of the IMF will depend on its ability to promote SDR as a global currency.

Attempts to tackle global currency problems contribute to the cooperation at a regional level. For example, China, Russia and Brazil agreed to settle bilateral trade transactions in yuans or rubles. In addition, China announced its willingness to increase gold reserves by buying gold for dollars from the IMF's reserves. Similar trends can also be observed in the case of Russia, which expressed its intention to make the ruble a regional currency. The first step towards achieving these goals is establishing a customs union between Russia, Belarus and Kazakhstan from mid 2010.

A reform of the IMF role in the world economy and a growing position of developing countries increase the chance for internationalization of their currencies. However, international currencies are usually issued by countries that have great economic potential (absolute GDP), with a large share of world exports, big and liquid financial markets and macroeconomic stability which ensures the purchasing power of money. This means that any significant increase in the importance of these currencies in the global economy would require an institutional 
reform which those countries have been trying to deal with unsuccessfully for many years.

\section{The EURo AS AN INTERNATIONAL CURRENCY}

The euro area largely satisfies the conditions necessary for the euro to play the role of international money (a large share of world trade and GDP, well-developed financial markets, economic and political stability). The euro as an international currency can be seen from the perspective of functions which it can play (a medium of exchange, store of value and a unit of account) and sectors where it is used. The first 10 years of experience of the euro functioning allow to formulate the following conclusions - see Table 1 .

Table 1. Features of international currencies according to the classification by Cohen

\begin{tabular}{|c|c|c|}
\hline Function & Public sector & Private sector \\
\hline Medium of exchange & $\begin{array}{c}\text { Intervention currency } \\
*\end{array}$ & $\begin{array}{c}\text { Vehicle currency } \\
*\end{array}$ \\
\hline Store of value & $\begin{array}{c}\text { Reserve currency } \\
* * *\end{array}$ & $\begin{array}{c}\text { Investment currency } \\
* * *\end{array}$ \\
\hline Unit of account & Anchor currency & $\begin{array}{c}\text { Invoicing currency in } \\
\text { international trade } \\
* *\end{array}$ \\
\hline
\end{tabular}

* - moderate rise in euro importance

** - significant rise in euro importance

*** - very large rise in euro importance

Source:EMU@10,EC, 2008.

First, the euro has become the second largest international currency as a result of macroeconomic stability ensuring its purchasing power. Confidence in the European currency is also based on a large economic potential of the euro area, which generated approximately $15 \%$ of global GDP in 2008, and at the same time the euro area was the world's largest exporter. Thanks to eliminating exchange rate risk of the euro, the euro has contributed to a very rapid integration of financial markets, not only in the euro area but also in an international dimension.

Secondly, as well as in the private and public sectors, the euro is mainly used in the geographical neighbourhood of the issuer in the EU and Europe, and to a lesser extent in Africa, Asia or South America. For countries such as Denmark, Great Britain and Sweden the euro area financial markets have become the most important source of capital (mainly through debt securities) and investment 
market. New EU Member States benefit from the deep credit market of the euro area. The New EU Member States and third countries outside the EU also use the euro as a nominal anchor to which about 40 currencies are linked (mostly European ones). At the same time the EU-level accumulation of foreign exchange reserves in euros is much higher, varying from $40 \%$ to $85 \%$.

Thirdly, the euro contributed to the international monetary and financial system stability during the first phase of the crisis (Knigth 2008). A benefit from the operation of several currencies in the international financial system is that global players have more freedom in the choice of the nominal anchor. For countries that have strong trade and investment links with the euro area, the use of the single currency will bring more benefits than the dollar. Moreover, universal access to more than one global currency allows for transaction risk reduction. Assessing the turbulence of the initial phases of the crisis, Knight (2008) points out that its consequences would probably have been more acute for the euro area and for the world but for the euro currency.

Fourthly, the fastest expansion of the common currency is visible in investment area. The greatest success of the euro has been noted as regards private debt instruments market. Financial institutions, including players from the EU 3 and non-euro countries (e.g. U.S.), have become the main beneficiaries of this segment. The use of the currency as an investment depends on the degree of liquidity and the quality of the financial markets (Goralczyk 2006). Despite fast financial market integration, the euro area lags behind the U.S. mainly in the stock market. This may be due to persistent fragmentation of the European stock markets and a more developed one in the United States. By contrast, in the debt securities market, common currency provides a counterbalance to the dollar. The share of the euro in 2008 was over $40 \%$ of the total bonds issued in the world. In the public sector, as regards the role of foreign exchange reserves, the use of the euro is smaller but progress has also been recorded. Given the fact that too rapid change in the structure of reserves could lead to instability of the international monetary system, an increase in the euro share (in the total reserves) from $18 \%$ in 1999 to $26.5 \%$ in 2008 can be considered a success.

Fifthly, the euro has also reached a high acceptance level as a unit of account, in both the private and public sectors. Having a means of payment that is widely accepted in the world, euro area enterprises can invoice a significant part of exports and imports in domestic currency. The euro has become widely used in transactions with partners outside the euro area (in 2007 slightly more than $50 \%$ of trade invoiced in the common currency). Benefits from the emergence of the euro have been felt by most countries whose national currencies in operation before the adoption of the euro traditionally played a small role (Spanish peseta, Portuguese escudo).

Table 2 shows that the average rate of use of the euro as an invoicing currency across the euro area was $49.7 \%$, while the rate for the dollar was $44 \%$ of the 
value of exports from outside the European Union. The euro is mostly used in Germany, Austria and Italy, but rarely in Greece and Luxembourg. In the case of imports we see a predominance of the dollar $(55.7 \%)$, which of course is related to the import of raw materials. The share of dollar in the invoicing of imports in Greece is as high as $80 \%$ and over $76 \%$ in the Netherlands.

Table 2. The euro's share as an invoicing currency in extra-EU exports and imports of goods of selected euro area countries

\begin{tabular}{|c|c|c|c|c|c|c|c|c|c|c|}
\hline \multicolumn{6}{|c|}{ EXPORT } & \multicolumn{5}{|c|}{ IMPORT } \\
\hline \multicolumn{2}{|l|}{$\stackrel{\Xi}{\Xi}$} & $\frac{\text { 흠 }}{\overline{0}}$ & $\frac{\pi}{2}$ & 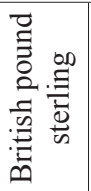 & 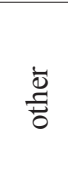 & $\stackrel{\Xi}{\Xi}$ & $\frac{\dot{\bar{\Xi}}}{\overline{\bar{\theta}}}$ & $\frac{\overline{0}}{2}$ & 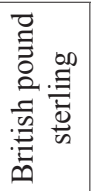 & $\stackrel{\bar{\Xi}}{ \pm}$ \\
\hline Austria & 62.9 & 23.4 & 0.0 & 0.0 & 13.7 & 60.9 & 27.2 & 0.0 & 0.0 & 11.9 \\
\hline Belgium & 50 & 36.9 & 0.9 & 12.3 & - & 46.3 & 41.8 & 2.0 & 9.9 & 0.0 \\
\hline Finland & 44 & 47.6 & - & - & 8.4 & 29.6 & 62.8 & - & - & 7.6 \\
\hline France & 43.2 & 50.5 & 2.2 & 0.2 & 3.9 & 32.9 & 60.3 & 2.0 & 0.1 & 4.7 \\
\hline Germany & - & - & - & - & - & 40.9 & 40.3 & 3.2 & 2.3 & 13.3 \\
\hline Greece & 28.1 & 70.7 & 0.3 & 0.2 & 0.7 & 18.0 & 80 & 0.8 & 0.2 & 1.0 \\
\hline Ireland & 46.1 & 50.1 & 0.8 & 0.7 & 1.8 & 19.4 & 69.3 & 0.7 & 0.2 & 10.3 \\
\hline Italy & 53.7 & 43.4 & - & - & 2.9 & 27.5 & 69.8 & - & - & 2.7 \\
\hline Luxemburg & 29.6 & 68 & 0.6 & 1.1 & 0.7 & 33.5 & 52.2 & 8.7 & 1.8 & 3.9 \\
\hline Netherland & 52.5 & 42.2 & 0.8 & 0.7 & 3.9 & 23.4 & 76.3 & 0.1 & 0.1 & 0.1 \\
\hline Portugal & 48.9 & 47.1 & 0.3 & 0.3 & 3.5 & 43.4 & 52.1 & 1.8 & 0.1 & 2.7 \\
\hline Spain & 53.6 & 43.4 & 1.2 & 0.1 & 1.7 & 44.2 & 54.4 & 0.7 & 0.0 & 0.7 \\
\hline Euro zone & 49.7 & 44 & - & - & 6.3 & 35.2 & 55.7 & - & - & 9.0 \\
\hline
\end{tabular}

Source: The international role of the euro, EBC 2009.

The above factors indicate that the euro should retain its status as the second international currency.

\section{Conclusions}

A lot of arguments indicate the risk that the US dollar might lose its importance as a consequence of high indebtedness in public and private sector and the abuse of the privilege of international currency. Taking into consideration the hitherto performance of the euro, including comparable financial markets liquidity, the depreciation of the US dollar may cause the euro appreciation, which can lead to deepening of the differences between the European countries.

Comparison of the euro area countries, concerning their capacity of the global competition, indicates deep disproportions. The economy with the relatively 
best position is the German economy. However, such countries as France, Italy or Spain experienced a decrease of their competitive position in international trade. Potential euro appreciation has a great importance since such countries as Greece, Ireland, Finland, Germany and Italy send only about $30-45 \%$ of their exports to the euro area.

The buffer against the rapid retreat from the US dollar and the appreciation of euro may be on the one hand the attachment of the world players to the USD, and on the other hand widening of convertibility of the surplus countries' currencies and creation of the local currency zones.

The euro area has been so far the most successful experiment in the hitherto evolution of the international monetary system. Moreover, such countries as China and Russia still differ a lot from the EU countries regarding the quality of their institutions and their political and macroeconomic stability. Therefore, the euro will probably gain more importance as an international currency, but it will happen to a different extent in the different segments of the market.

Regardless of the euro depreciation from the beginning of 2010, the common currency has gained critical mass to remain the second most important currency. Latest appreciation of the USD can be explained by rising fears in some segments of the financial systems. In a short run currency movements are determined by capital flows - so we can observe the wave of increasing/decreasing value of the USD and the euro.

We do not observe the crisis of the euro area, we do not experience crisis of the euro as a global currency. What we observe is a problem of a few countries and to some extent we should be happy that markets differentiate the sovereign risk. The euro as a local and global currency can be an umbrella but when the rain is a long-term phenomenon, you should worry not only about your head but also about fundamentals on which you are based. One of the keys to resolve problem is to improve mechanisms of the cooperation and integration in the fiscal policy area.

\section{REFERENCES}

Bordo M., Harold J., (2008), A Long Term Perspective on the Euro, NBER Working Paper. Bukowski S.I., (2007), Unia monetarna. Teoria i praktyka, Difin, Warsaw.

EMU@10, European Commission, 2008.

Elsake S., (2009), Is the US Dollar in Danger of Losing its Reserve Currency Status?, Australia and New Zealand Banking Group Ltd., July.

Fratzscher M., (2009), What Explains Global Exchange Rate Movements During the Financial Crisis?, ECB Working Paper, No. 1060.

Góralczyk M., (2009), Dolar i Euro jako waluty międzynarodowe, http://konkursoeuro.pl/resources/files/dolar_i_euro.pdf (as of 20 September, 2009).

Górka J. (2007), Waluta światowa - dolar versus euro, Rachunkowość bankowa.

Knight D. (2008), The Euro as a Catalyst for Global Financing Market Deepening, BIS, 2008.

Kozioł W., (2003), Konsekwencje wprowadzenia euro przez. Polskę, [in:] Nowak A. Z., 
Stępniak A.(ed.) Strefa euro - wyzwania dla Polski, WWZ, Warsaw.

Persaud A., (2001), Międzynarodowa rola euro, [in:] Temperton P. (ed.) Euro. Wspólna walu$t a$, Felberg SJA, Warszawa.

Raport nt. petnego uczestnictwa Rzeczypospolitej Polskiej w trzecim etapie Unii Gospodarczej $i$ Walutowej, NBP, 2009.

Tchorek G., Gromiec Z., (2009), Kryzys a przemiany w międzynarodowym systemie walutowym. Implikacje dla strefy euro i Polski. NBP November.

The international role of the euro, EBC 2009.

\title{
KRYZYS FINANSOWY A PRZEMIANY W MIĘDZYNARODOWYM SYSTEMIE WALUTOWYM. IMPLIKACJE DLA EURO
}

Słowa kluczowe: waluta międzynarodowa, euro, kryzys, system walutowy, integracja walutowa

\begin{abstract}
Abstrakt: Obok wielu korzyści wynikających z posiadania waluty międzynarodowej występują również istotne ograniczenia. Bez wątpienia dobrze jest posiadać pieniądz międzynarodowy, jednak sam proces zdobywania statusu waluty międzynarodowej może prowadzić do pewnych kosztów związanych z aprecjacją euro. Głównym celem artykułu jest wskazanie, że jeden z prawdopodobnych scenariuszy, jaki ukształtuje się w wyniku kryzysu, może zwiększać ryzyko przewartościowania euro. Wynika to ze zmniejszającej się roli dolara amerykańskiego i relatywnie płynnego przejęcia przez euro roli drugiej waluty międzynarodowej. Paradoksalnie, dzięki swoim sukcesom, euro może być narażone na nadmierną aprecjację z istotnymi implikacjami zarówno dla funkcjonowania samej strefy euro, jak i krajów do niej kandydujących.
\end{abstract}


